\title{
Lichenicolous fungi from the Samara Region, southern part of European Russia
}

\author{
Andrei Tsurykau ${ }^{1,2} \&$ Evgeny S. Korchikov ${ }^{2}$ \\ ${ }^{1}$ Department of Biology, F. Skorina Gomel State University, Sovetskaja st. 104, 246019 Gomel, Belarus. \\ E-mail: tsurykau@gmail.com \\ ${ }^{2}$ Department of Ecology, Botany and Nature Protection, Institute of Natural Sciences, Samara National Research \\ University, Moskovskoye shosse 34, 443086 Samara, Russia. \\ E-mail: evkor@inbox.ru
}

\begin{abstract}
Twenty two species of lichenicolous and two occasionally lichen-inhabiting fungi are reported from the Samara Region. Twenty three of them are new to the region, eighteen - to southern part of European Russia; Intralichen lichenum is new to European Russia, and Phoma grumantiana and Pyrenidium crozalsii are reported for the first time for Russia.
\end{abstract}

Keywords: biodiversity; distribution; new records

\section{INTRODUCTION}

Lichenicolous fungi in Russia are studied very unevenly. The main data concern its Arctic part, Karelia, Ural Mountains and the Caucasus (e.g. Zhurbenko, 2007 and literature cited therein) while large territories in European and Asian parts of Russia are understudied. This also concerns 'Southern part of European Russia' (Es) according to Andreev \& Himelbrant (2014), which remains one of the least explored areas in Russia in respect to lichenicolous fungi. In total, 9 species of lichenicolous fungi can be enumerated from the area, namely Arthonia epiphyscia Nyl., A. hertelii (Calat., Barreno \& V.J. Rico) Hafellner \& V. John, A. urceolata (Elenkin) V.J. Rico, Calat. \& Barreno, Cercidospora epicarphinea (Nyl.) Grube et Hafellner, C. macrospora (Uloth) Hafellner et Nav.-Ros., Echinothecium reticulatum Zopf, Illosporiopsis christiansenii (B. L. Brady \& D. Hawksw.) D. Hawksw., Muellerella erratica (A. Massal.) Hafellner \& V. John, M. pygmaea (Körb.) D. Hawksw. s. lat. and Trichonectria rubefaciens (Ellis \& Everh.) Diederich \& Schroers (Merkulova, 2006; Zhurbenko, 2007; Korchikov et al., 2014, 2015; Korchikov \& Travkin, 2015).

In the Samara Region lichenicolous fungi were neglected until very recently, when Korchikov et al. (2015) reported Illosporiopsis christiansenii and Trichonectria rubefaciens from Zhiguli Mts. as new to the area. Here we present 22 species of lichenicolous and two occasionally lichen-inhabiting fungi from the Samara Region.
Of these, 23 are recorded for the first time for the Samara Region, southern part of European Russia, European Russia or Russia.

\section{STUDY AREA}

The Samara Region is a large $\left(53600 \mathrm{~km}^{2}\right)$ territory of southern European Russia, located within $47-52^{\circ} \mathrm{N}$ and $51-54^{\circ} \mathrm{E}$ (Poroshina, 2002). The region borders three Russian administrative regions (Saratov, Ulyanovsk, Orenburg), the Republic of Tatarstan and Kazakhstan (Fig. 1). The main part of the region comprises flat lowland terrain. The central part has rugged relief (Zhiguli Mts., Fig. 2) with the highest point reaching $381 \mathrm{~m}$, the only mountainous area of tectonic origin throughout the East European platform. The main rocks, outcrops and cliffs are formed of limestone, dolomite and gypsum (Poroshina, 2002; Chistova \& Saksonov, 2004).

The climate of the region is continental. Average temperatures in July vary from $+19.3^{\circ} \mathrm{C}$ in the northeast to $+21.9^{\circ} \mathrm{C}$ in the southwest, in January from $-13^{\circ} \mathrm{C}$ in western part to $-14.5^{\circ} \mathrm{C}$ in the southeast. The annual mean precipitation does not exceed $300 \mathrm{~mm}$ in southwestern and ca. $450 \mathrm{~mm}$ in northeastern part of the Region (Poroshina, 2002).

The natural vegetation in the area is mainly represented by meadow steppes and desert steppes (Fig. 3) with fescue-feather, fescuewormwood and sagebrush communities (Golov- 

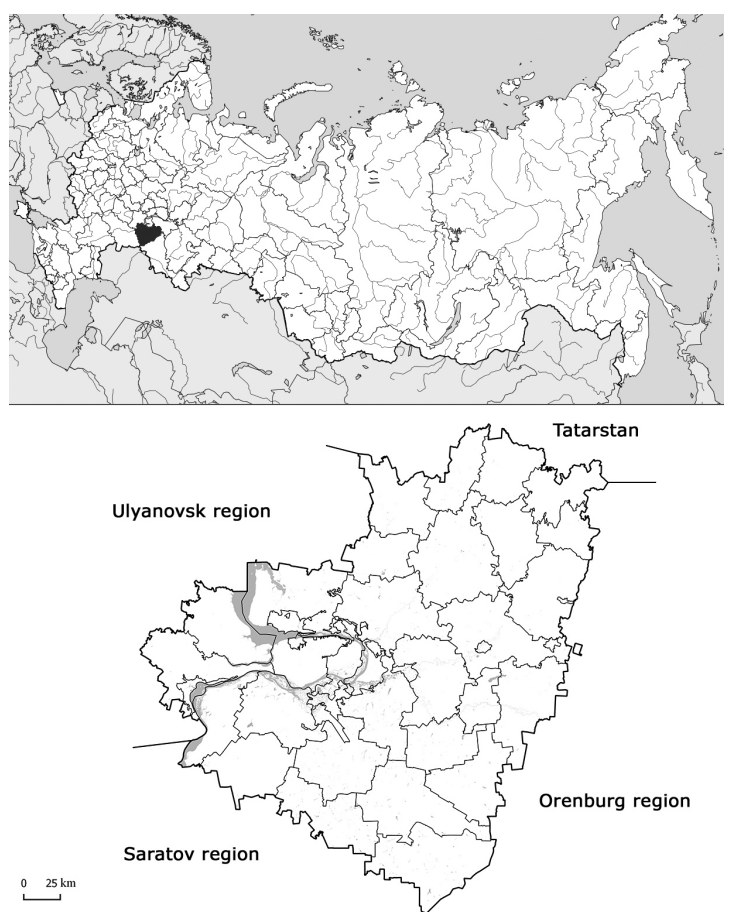

Fig. 1. Location of the study area (Samara Region).

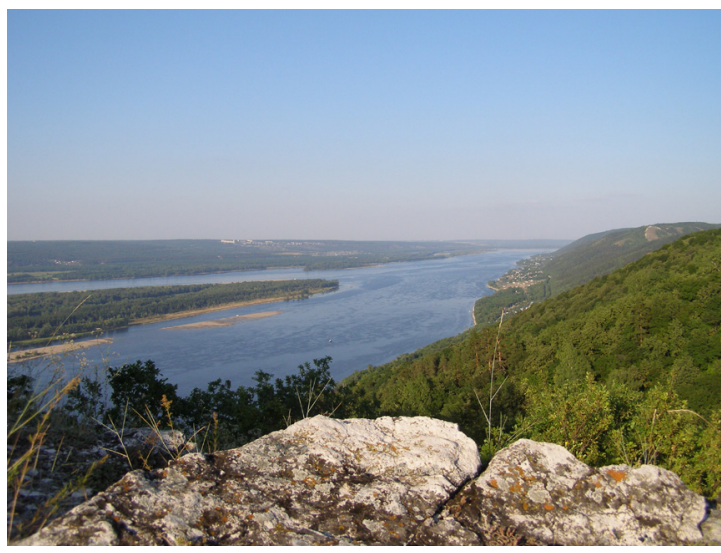

Fig. 2. Bol'shaya Bakhilovaya Mt. and Volga river (I. I. Sprygin Zhigulevskij State Reserve).

lev \& Prokhorova, 2008). Forests cover less than $13 \%$ of the total area and are confined either to northern part of the region or to the river valleys. Forests are mainly dominated by Quercus robur, while the other common trees are Acer platanoides, Betula pendula and Tilia cordata.
In the floodplain areas the most common trees are Alnus glutinosa, Betula pendula, Populus nigra, P. tremula, Salix alba, and Ulmus glabra. Pine forests which cover Zhiguli Mts. as well as limestone and dolomite sandy soils are considered relict (Gerasimova, 1971; Poroshina, 2002; Kudinov, 2007).

The modern landscape of the steppes mostly consists of agricultural areas as 95\% of the Samara Region is economically managed. Main biodiversity is located within protected areas, viz. a nature reserve, two national parks and 214 monuments of nature (Poroshina, 2002; Golovlev \& Prokhorova, 2008; Pazhenkov, 2010).

\section{MATERIAL AND METHODS}

The material was collected mainly by the second author during field studies in different parts of the Samara Region. Cited specimens are housed in the herbaria of Samara National Research University (SMR) and F. Skorina Gomel State University (GSU, one specimen). The material was examined using dissecting microscope MicroMed MC-2 and compound microscope MicMed 6; valuable and taxonomically critical

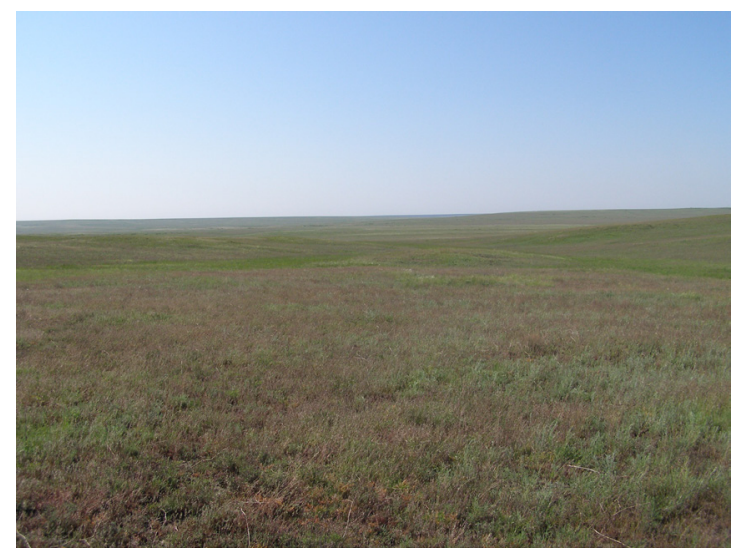

Fig. 3. Grass-wormwood steppe, monument of nature "Gryzly - desert steppes".

material was additionally studied using Nikon SMZ 745 and Nikon Eclipse 80i microscopes. Microscopic examination was done in water, $10 \% \mathrm{KOH}(\mathrm{K})$, Lugol's iodine, directly (I) or after a $\mathrm{KOH}$ pre-treatment (K/I). Measurements were taken from water mount. Values are indicated as 
(minimum- $)\{\mathrm{X}-\mathrm{SD}\}-\{\mathrm{X}+\mathrm{SD}\}(-$ maximum), where $\mathrm{X}$ is the arithmetic mean and SD the corresponding standard deviation, followed by the number of measurements. The names of the main collectors in the species list are abbreviated as follows: EK - Evgeny S. Korchikov, VT - Vladimir P. Travkin.

\section{THE SPECIES}

ABRoTHALlus SUECICUS (Kirschst.) Nordin (anamorph) - Kinel district, Krasnosamarskoje forest, $52^{\circ} 29^{\prime} \mathrm{N}, 51^{\circ} 03^{\prime} \mathrm{E}$, linden forest, on Ramalina pollinaria, EK, 27.06.2004 (SMR 909).

Note. New to Es. Distribution in European Russia: Republic of Karelia (Zhurbenko \& Ahti, 2005).

Athelia ARAchnoidea (Berk.) Jülich - Kinel district, Krasnosamarskoje forest, Samara river floodplain, $52^{\circ} 59^{\prime} \mathrm{N}, 51^{\circ} 04^{\prime} \mathrm{E}$, lindenaspen forest, on Physcia tenella and Xanthoria parietina, EK, 08.07.2008 (SMR 1148); same forest, $52^{\circ} 59^{\prime} \mathrm{N}, 51^{\circ} 03^{\prime} \mathrm{E}$, oak-linden forest, on Melanohalea exasperata, EK, 29.06.2005 (SMR 647); Krasnoyarsk district, natural monument “Shilanskiye Genkovskiye Lesopolosy", 5330'N, $50^{\circ} 33^{\prime} \mathrm{E}$, ash-maple forest, on Xanthomendoza fallax and Physconia distorta, K. S. Kharitonova, 04.09.2016 (SMR 1155).

Note. New to the Samara Region. This necrotrophic basidiomycete is common in European countries and inhabits lichens, algae, mosses, leaf litter, bark and wood (see e.g. Yurchenko \& Golubkov, 2003). According to Zmitrovich (2004), the species is widely distributed throughout the whole territory of Russia.

Clypeococcum hypocenomycis D. Hawksw. Borskij district, Buzulukskij Bor National Park, Koltubanovskij forest, $52^{\circ} 58^{\prime} \mathrm{N}, 52^{\circ} 00^{\prime} \mathrm{E}$, pine forest, VT, 20.05.2014 (SMR 126); same forest, $52^{\circ} 58^{\prime} \mathrm{N}, 52^{\circ} 03^{\prime} \mathrm{E}$, top of a ridge on the river Samara fluvial terrace, EK, 05.08.2014 (SMR 1161); Krasnoyarsk district, close to Zharenyj Bugor village, $53^{\circ} 33^{\prime} \mathrm{N}, 50^{\circ} 16^{\prime} \mathrm{E}$, mixed forest, E. S. Sochneva, 11.06.2016 (SMR 1052); all on Hypocenomyce scalaris (thallus).

Note. New to Es. In European Russia, this widespread lichenicolous fungus has been reported from many regions from Kaliningrad Region
(Dedkov et al., 2006) to Komi Republic (Zhurbenko, 2007).

Cornutispora lichenicola D. Hawksw. \& B. Sutton - Kinel district, Krasnosamarskoje forest, $52^{\circ} 58^{\prime} \mathrm{N}, 51^{\circ} 01^{\prime} \mathrm{E}$, birch forest, on Hypogymnia physodes, EK, 10.07.2004 (SMR 493).

Note. New to Es. Distribution in European Russia: Leningrad, Murmansk and Tula Regions, Republic of Karelia, and Komi Republic (Alstrup et al., 2005; Zhurbenko, 2004, 2009a; Himelbrant et al., 2013; Zhurbenko \& Gudovicheva, 2013).

HeterocephalacRia PHYSCIACEARUM (Diederich) Millanes \& Wedin - Borskij district, Buzulukskij Bor National Park, Koltubanovskij forest, $52^{\circ} 59^{\prime} \mathrm{N}, 51^{\circ} 59^{\prime} \mathrm{E}$, mixed forest, on Physcia aipolia (thallus), VT, 20.05.2014 (SMR 502).

Note. New to Es. In European Russia the species was known in Leningrad Region, Republics of Bashkortostan, Karelia and Mordovia, and Komi Republic (Alstrup et al., 2005; Zhurbenko, 2007; Himelbrant et al., 2013; Urbanavichene et al., 2013; Urbanavichene \& Urbanavichus, 2016).

IntRalichen Christiansenii (D. Hawksw.) D. Hawksw. \& M. S. Cole - Stavropolskij district, I. I. Sprygin Zhigulevskij State Reserve, Gudronnyj area, $53^{\circ} 23^{\prime} \mathrm{N}, 49^{\circ} 45^{\prime} \mathrm{E}$, birch forest, on Lecania sp. (apothecia), EK, 16.08.2008 (SMR 110); same district, Samarskaya Luka National Park, monument of nature "Mogutovaya Gora", northern slope, $53^{\circ} 25^{\prime} \mathrm{N}, 4^{\circ} 30^{\prime} \mathrm{E}$, herbage-feather grass steppe, on Caloplaca sp. (apothecia), E. D. Iljina, 10.06.2015 (SMR 535); same locality, western slope, $53^{\circ} 25^{\prime} \mathrm{N}, 4^{\circ} 29^{\prime} \mathrm{E}$, herbage-feather grass steppe, on Candelariella sp., EK, 03.05.2014 (SMR 980); same place, on Caloplaca saxicola, E. D. Iljina, 03.05.2014 (SMR 1087).

Note. New to Es. In European Russia this widespread species has been reported from Komi Republic, Republic of Bashkortostan and Nenets Autonomous Area (Zhurbenko, 2008; Urbanavichus \& Urbanavichene, 2011; Zhurbenko et al., 2012).

InTRALICHEN LICHENUm (Diederich) D. Hawksw. \& M. S. Cole - Stavropolskij district, Samarskaya Luka National Park, $2 \mathrm{~km}$ E of Bolshaya Ryazan village, $53^{\circ} 15^{\circ} \mathrm{N}, 49^{\circ} 20^{\circ} \mathrm{E}$, aspen forest, on $L e$ cania cyrtella (apothecia), EK, 14.08.2008 (SMR 519, SMR 522). 
Note. New to European Russia. The species has been recently reported as new to the country from the Republic of Adygeya (Zhurbenko \& Kobzeva, 2016). Our samples were characterized by subspherical, brownish, simple, smooth conidia (3.0-)3.4-4.4(-5.0) × (2.5-)2.8-3.7(4.5) $\mu \mathrm{m}, \mathrm{n}=50$, arranged in sometimes brached chains composed of 2-9 conidia. This species is most similar to Intralichen christiansenii, which differs in generally larger $(5-8 \times 4-6 \mu \mathrm{m}) 1$-septate conidia (Hawksworth, 1979; Hawksworth $\&$ Cole, 2002).

LiCHENOCHORA OBSCUROIDES (Linds.) Triebel \& Rambold - Borskij district, Buzulukskij Bor National Park, Koltubanovskij forest, $52^{\circ} 59^{\prime} \mathrm{N}$, $51^{\circ} 59^{\prime} \mathrm{E}$, mixed forest, VT, 20.05.2014 (SMR s. n.); same forest area, $52^{\circ} 59^{\prime} \mathrm{N}, 52^{\circ} 01^{\prime} \mathrm{E}$, linden forest, VT, 04.08.2014 (SMR 1152); Kinel district, Kinel forest, $53^{\circ} 04^{\prime} \mathrm{N}, 51^{\circ} 03^{\prime} \mathrm{E}$, aspen forest, EK, 22.07.2007 (SMR 177), all on thalli of Phaeophyscia orbicularis.

Note. New to Es. In European Russia the species was known from Kaliningrad and Leningrad Regions and Republic of Bashkortostan (Frolov \& Paukov, 2005; Dedkov et al., 2006; Himelbrant et al., 2016).

Lichenoconium erodens M. S. Christ. \& D. Hawksw. - Borskij district, Buzulukskij Bor National Park, Koltubanovskij forest, $52^{\circ} 56$ 'N, $52^{\circ} 01^{\prime} \mathrm{E}$, pine forest, on Hypogymnia physodes (thallus), VT, 20.05.2014 (SMR 1151); Kamyshla district, $1 \mathrm{~km}$ N Novoje Usmanovo village, $54^{\circ} 07^{\prime} \mathrm{N}, 52^{\circ} 21^{\prime} \mathrm{E}$, broadleaved forest, on Evernia prunastri (thallus), EK, 06.10.2010 (SMR 1149); Kinel district, Kinel forest, $53^{\circ} 25^{\prime} \mathrm{N}, 49^{\circ} 43^{\prime} \mathrm{E}$, birch forest, on Bryoria nadvornikiana (thallus), EK, 07.07.2007 (SMR 123); same forest, $52^{\circ} 58^{\prime} \mathrm{N}, 51^{\circ} 02^{\prime} \mathrm{E}$, pine forest, on Parmelia sulcata (thallus), EK, 02.07.2004 (SMR 26); Krasnosamarskoje forest, $52^{\circ} 59^{\prime} \mathrm{N}, 51^{\circ} 02^{\prime} \mathrm{E}$, oak-linden forest, on Melanohalea exasperata (thallus), EK, 29.06.2005 (SMR 1127); same area, $52^{\circ} 59^{\prime} \mathrm{N}, 51^{\circ} 02$ 'E, pine forest, on Lecanora sp. (apothecia), EK, 26.05.2005, (SMR 545); same area, $53^{\circ} 00^{\prime} \mathrm{N}, 51^{\circ} 00^{\prime} \mathrm{E}$, birch forest, on Parmeliopsis ambigua (thallus), EK, 19.07.2005, (SMR 792); same area, $53^{\circ} 02^{\prime} \mathrm{N}, 51^{\circ} 04^{\prime} \mathrm{E}$, oaklinden forest, on Ramalina farinacea (thallus), EK, 20.07.2003, (SMR 898); same area, $52^{\circ} 58^{\prime} \mathrm{N}$, $51^{\circ} 01^{\prime} \mathrm{E}$, birch forest, on Usnea scabrata (thallus), EK, 18.07.2004, (SMR 966); same area, $53^{\circ} 00^{\prime} \mathrm{N}, 51^{\circ} 02^{\prime} \mathrm{E}$, oak forest, on Evernia mesomorpha (thallus), EK, 15.07.2004, (SMR 445); Krasnoyarsk district, close to Novyj Buyan village, $53^{\circ} 41^{\prime} \mathrm{N}, 50^{\circ} 03^{\prime} \mathrm{E}$, oak-linden forest, on Parmelia sulcata (thallus), I. N. Goreslavets, 10.09.1989 (SMR 447); Syzran district, close to Rameno village, $53^{\circ} 14^{\prime} \mathrm{N}, 48^{\circ} 22^{\prime} \mathrm{E}$, broadleaved forest, on Evernia prunastri (thallus), T. M. Matyunina, 07.09.2013 (SMR 443).

Note. New to Es. The species seems to be the most common lichenicolous fungus within the study area inhabiting a wide range of host lichens. Lichenoconium erodens is a widespread species in European Russia being known from Arkhangelsk, Kaliningrad and Leningrad Regions, Republics of Karelia and Mordovia, and Komi Republic (Zhurbenko \& Santesson, 1996; Zhurbenko \& Himelbrant, 2002; Zhurbenko, 2004; Dedkov et al., 2006; Himelbrant et al., 2014; Urbanavichene \& Urbanavichus, 2016).

Lichenoconium LeCANoRAe (Jaap) D. Hawksw. - Borskij district, Buzulukskij Bor National Park, Koltubanovskij forest, $52^{\circ} 57^{\prime} \mathrm{N}, 51^{\circ} 57^{\prime} \mathrm{E}$, broadleaved forest, on Flavopunctelia soredica (thallus), EK, 01.08.2014 (SMR 1154).

Note. New to Es. In European Russia this widespread species was reported from Arkhangelsk, Kaliningrad, Leningrad and Murmansk Regions, Republic of Karelia and Komi Republic (Zhurbenko \& Santesson, 1996; Zhurbenko \& Himelbrant, 2002; Zhurbenko, 2004, 2009a; Dedkov et al., 2006; Kuznetsova et al., 2012).

Lichenoconium Pyxidatae (Oudem.) Petr. \& Syd. Borskij district, Buzulukskij Bor National Park, Koltubanovskij forest, $52^{\circ} 58^{\prime} \mathrm{N}, 52^{\circ} 03^{\prime} \mathrm{E}$, top of a ridge on the river Samara fluvial terrace, pine forest, on Cladonia botrytes (apothecia), EK, 05.08.2014 (SMR 1162).

Note. New to Es. In European Russia the species has been reported from Arkhangelsk and Tula Regions (Zhurbenko \& Santesson, 1996; Zhurbenko \& Gudovicheva, 2013).

LiCHENODIPLIS LECANORAE (Vouaux) Dyko \& D. Hawksw. - Kinel district, Krasnosamarskoje forest, Samara river floodplain, $52^{\circ} 59^{\prime} \mathrm{N}, 51^{\circ} 03^{\prime} \mathrm{E}$, oak-linden forest, on Lecania cyrtella (apothecia), EK, 07.07.2004 (SMR 521); same locality, on Lecanora sp., EK, 23.09.2007 (SMR 668).

Note. New to Es. Distribution in European Russia: Leningrad Region and Republic of Mordovia 
(Stepanchikova et al., 2011; Urbanavichene \& Urbanavichus, 2016).

LiCHenOSTIGMA MAURERI Hafellner - Kinel district, Krasnosamarskoje forest, Samara river floodplain, $53^{\circ} 00^{\prime} \mathrm{N}, 51^{\circ} 00^{\prime} \mathrm{E}$, birch forest, on Usnea subfloridana (thallus), EK, 10.07.2005 (SMR 970).

Note. New to Es. The species is widespread in European Russia being known from Leningrad and Vladimir Regions, Republics of Karelia and Mordovia, and Komi Republic (Alstrup et al., 2005; Zhurbenko, 2004; Kuznetsova et al., 2012; Zhurbenko et al., 2012; Zhurbenko \& Zhdanov, 2013; Urbanavichene \& Urbanavichus, 2016).

Muellerella lichenicola (Sommerf. ex Fr.) D. Hawksw. - Stavropolskij district, Samarskaya Luka National Park, monument of nature "Mogutovaya Gora", northern slope, $53^{\circ} 25^{\prime} \mathrm{N}$, $49^{\circ} 30^{\prime} \mathrm{E}$, herbage-feather grass steppe, on $\mathrm{Ca}$ loplaca sp. (apothecia), E. D. Iljina, 10.06.2015 (SMR 535).

Note. New to Es. Formerly known in European Russia from Arkhangelsk, Kaliningrad and Murmansk Regions and Republic of Bashkortostan (Zhurbenko \& Santesson, 1996; Dedkov et al., 2006; Zhurbenko, 2009a; Urbanavichus \& Urbanavichene, 2011).

Muellerella pygmaea (Körb.) D. Hawksw. var. PYGMAEA - Stavropolskij district, I. I. Sprygin Zhigulevskij State Reserve, Strelnaya Mt., $53^{\circ} 26^{\prime} \mathrm{N}, 49^{\circ} 45^{\prime} \mathrm{E}$, stony steppe, on Acarospora cervina, E. A. Petrova, 15.09.2012 (SMR 5).

Note. The species was previously reported for southern part of European Russia (lower portion of Volga basin) by Zhurbenko (2007) as $M$. pygmaea s. lat. on the basis of historical collection by V. P. Savicz. Here we report this species as new to the Samara Region. Distribution in European Russia: Komi Republic (Zhurbenko, 2009b; Zhurbenko et al., 2012).

Niesslia cladonitcola D. Hawksw. \& W. Gams - Stavropolskij district, I. I. Sprygin Zhigulevskij State Reserve, Gudronnyj area, $53^{\circ} 23^{\prime} \mathrm{N}$, $49^{\circ} 45^{\prime} \mathrm{E}$, birch forest, on Cladonia squamosa, EK, 16.08.2008 (SMR 358).

Note. New to Es. In European Russia this infrequently recorded species has been reported from Leningrad Region and Republic of Karelia (Alstrup et al., 2005; Himelbrant et al., 2014).

Phoma grumantiana Zhurb. \& Diederich - Kinel district, Krasnosamarskoje forest, $52^{\circ} 59^{\prime} \mathrm{N}$, $50^{\circ} 58^{\prime} \mathrm{E}$, edge of pine forest, on Cladonia rei (primary thallus), EK, 06.05.2008 (SMR 1156).

Note. New to Russia. The species has previously been reported from Italy, Luxembourg, Svalbard, Spain and the USA (Diederich et al., 2007, 2009; van den Boom \& Etayo, 2014; Brackel $\&$ Puntillo, 2016). Conidia in our specimen are simple, hyaline, oblong to ellipsoid, apically rounded, with a small guttule near each apex, $(3.5-) 3.8-4.5(-5.5) \times(1.5-) 1.8-2.1(-2.5) \mu \mathrm{m}, 1 / \mathrm{b}$ (1.5-)2.0-2.4(-3.0), $n=100$. Other members of the genus parasitizing Cladonia species, Phoma cladoniicola Diederich, Kocourk. \& Etayo and $P$. foliaceiphila Diederich, Kocourk. \& Etayo, differ by larger conidia, which are 4.7-5.9 × 2.4-3.0 $\mu \mathrm{m}$ in P. cladoniicola and $5.8-7.1 \times 2.2-2.7 \mu \mathrm{m}$ in $P$. foliaceiphila (Diederich et al., 2007).

Pronectria Robergei (Mont. et Desm.) Lowen (anamorph) - Bolshechernigovskij district, monument of nature "Gryzly - desert steppes", $51^{\circ} 46^{\prime} \mathrm{N}, 50^{\circ} 45^{\prime} \mathrm{E}$, fescue-feather grass steppe, on Peltigera didacyla (thallus), EK, 09.05.2012 (SMR 1150).

Note. New to Es. The species is widely distributed in European Russia being previously known in Kaliningrad, Kaluga, Murmansk and Tula Regions, Republic of Karelia, Komi Republic and Nenets Autonomous Area (Zhurbenko \& Himelbrant 2002; Zhurbenko, 2004, 2008; Dedkov et al., 2006; Urbanavichus et al., 2007; Gudovicheva \& Himelbrant, 2012).

Pyrenidium CROZAlsi (Vouaux) Nav.-Ros. \& Cl. Roux - Stavropolskij district, I. I. Sprygin Zhig-

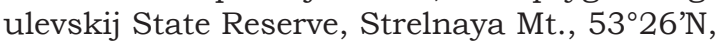
$49^{\circ} 45^{\prime} \mathrm{E}$, stony steppe, on Caloplaca aurantia on exposed calcareous rocks, E. A. Petrova, 15.09.2012 (SMR 1157).

Note. New to Russia. The species is rarely reported from Europe, being known from Austria (Hafellner \& Wieser, 2000), Italy and France (Clauzade et al., 1989; Roux, 2012). Perithecia in small groups, black, ostiolate, c. $150 \mu \mathrm{m}$; hamathecium I-, K/I-; paraphysoids well developed, numerous, filiform, hyaline, septate, abundantly branched and anastomosed, longer 
than asci, 1.5-2.0 $\mu \mathrm{m}$ wide; asci clavate, stipitate, bitunicate (fissitunicate), 8-spored, 80-95 $\times 15-17 \mu \mathrm{m}$; spores broadly ellipsoid, brown, (1-)3-septate, slightly constricted at the septa, with shorter end cells, guttulate, with 4 large guttules disappearing with age, (17.0-)18.9$22.1(-23.0) \times(6.0-) 6.5-8.2(-9.0) \mu \mathrm{m}, \mathrm{n}=25$. The characteristics of our specimen fit mostly the original description in Vouaux (1913), except for he stated some mature asci to be 4-spored. Pyrenidium actinellum s. lat. has also been reported from Caloplaca, however, it differs by larger spores $(20-30 \times 7-10 \mu \mathrm{m})$ and mainly 4-spored asci (Navarro-Rosines \& Roux, 2007).

Taeniolella Beschiana Diederich - Borskij district, Buzulukskij Bor National Park, Koltubanovskij forest, $52^{\circ} 58^{\prime} \mathrm{N}, 52^{\circ} 03^{\prime} \mathrm{E}$, top of a ridge on the river Samara fluvial terrace, pine forest, on Cladonia phyllophora, EK, 05.08.2014 (SMR 1164); Volzhskij district, close to " $154 \mathrm{~km}$ " station, $53^{\circ} 26^{\prime} \mathrm{N}, 50^{\circ} 09^{\prime} \mathrm{E}$, pine forest, on Cladonia rei (primary thallus), EK, 16.05.2005 (GSU 229).

Note. New to Es. Distribution in European Russia: Arkhangelsk and Murmansk Regions, Republics of Bashkortostan and Karelia (Zhurbenko \& Santesson, 1996; Zhurbenko \& Himelbrant, 2002; Zhurbenko \& Alstrup, 2004; Urbanavichus \& Urbanavichene, 2011).

Taeniolella phaeophysciae D. Hawksw. - Kinel district, Krasnosamarskoje forest, $52^{\circ} 59^{\prime} \mathrm{N}$, $51^{\circ} 02^{\prime} \mathrm{E}$, aspen forest, on Phaeophyscia ciliata (thallus), E. A. Gafiyatova \& E. A. Petrova, 17.07.2009 (SMR 774); Volzhskij district, Sorochinskije Mts., close to the city of Samara, $53^{\circ} 20^{\prime} \mathrm{N}, 50^{\circ} 13^{\prime} \mathrm{E}$, broadleaved forest, on $P$. orbicularis, Ju. V. Khot'ko, 29.09.2016 (SMR 1153).

Note. New to Es. In European Russia the species has been reported from Tula Region and Komi Republic (Zhurbenko et al., 2012; Zhurbenko \& Gudovicheva, 2013).

TAEniolina scriPTA (P. Karst.) P. M. Kirk - Stavropolskij district, I. I. Sprygin Zhigulevskij State Reserve, Malinovyj ravine, $53^{\circ} 25^{\prime} \mathrm{N}, 49^{\circ} 40^{\prime} \mathrm{E}$, maple-linden forest, on Biatora carneoalbida (thallus), E. A. Sinichkin, 15.09.2013 (SMR 108).

Note. New to Es. The species inhabits different substrates and its occurrence on lichens is secondary. In European Russia it was previously reported from the Leningrad Region growing on bark of Betula pubescens and lignum (Mel'nik, 2000).

TRICHONECTRIA RUBEFACIENS (Ellis \& Everh.) Diederich \& Schroers - Kinel district, Krasnosamarskoje forest, $52^{\circ} 59^{\prime} \mathrm{N}, 51^{\circ} 03^{\prime} \mathrm{E}$, oak-linden forest, on Melanohalea exasperata (thallus), EK, 29.06.2005 (SMR 647).

Note. This is the second record for the Samara Region after Korchikov et al. (2015). The species was recently reported as new to European (Kuznetsova et al., 2012; Gudovicheva \& Himelbrant, 2012) and Asian (Zhurbenko, 2014) parts of Russia.

XANTHORIICOla PHYSciae (Kalchbr.) D. Hawksw. Kinel district, Krasnosamarskoje forest, $53^{\circ} 02^{\prime} \mathrm{N}$, $50^{\circ} 59^{\prime} \mathrm{E}$, black poplar woodland, on Xanthoria parietina (apothecia), EK, 23.09.2007 (SMR 1011).

Note. New to Es. Formerly known in Russia from Leningrad Region (Stepanchikova et al., 2011), Stavropol Territory (Zhurbenko \& Kobzeva, 2014) and Republic of Mordovia (Urbanavichene \& Urbanavichus, 2016).

\section{ACKNOWLEDGEMENTS}

We thank Mikhail P. Zhurbenko (Saint Petersburg) for valuable suggestions, corrections and improvements, Jurga Motiejūnaite (Vilnius) for the help with literature and Tiina Randlane (Tartu) for the linguistic corrections and useful comments on the manuscript.

\section{REFERENCES}

Alstrup, V., Zavarzin, A. A., Kocourkova, J., Kravchenko, A. V., Fadeeva, M. A. \& Shiefelbein, U. 2005. Lichens and lichenicolous fungi found in northern Ladoga Lake region (Karelia Republic) during an international field excursion in August 2004 before V IAL Congress. - Trudy Karel'skogo Nauchnogo Tsentra RAN 7: 3-15. (In Russian).

Andreev, M. P. \& Himelbrant, D. E. 2014. The lichen flora of Russia. Biology, ecology, diversity, distribution and methods to study lichens. Saint Petersburg. 392 pp. (In Russian).

van den Boom, P. P. G. \& Etayo, J. 2014. New records of lichenicolous fungi and lichenicolous lichens from the Iberian Peninsula, with the description of four new species and one new genus. Opuscula Philolichenum 13: 44-79. 
Brackel, W. von \& Puntillo, D. 2016. New records of lichenicolous fungi from Calabria (southern Italy), including a first checklist. Herzogia 29: 277-306. https://doi.org/10.13158/heia.29.2.2016.277

Chistova, V. V. \& Saksonov, S. V. 2004. Pearl of Russia. Samara Bend (National Park 20-years anniversary). Zhigulevsk. 192 pp. (In Russian).

Clauzade, G., Diederich, P. \& Roux, C. 1989. Nelikeniĝintaj fungoj likenloĝaj. Ilustrita determinlibro. Bulletin de la Société Linnéenne de Provence 1: 1-142.

Dedkov, V. P., Andreev, M. P. \& Petrenko, D. E. 2006. Annotated checklist of lichens and lichenicolous fungi of Kalinigrad Region. In: Dedkov, V. P. \& Gubareva I, Ju (eds). Biodiversity of Kaliningrad Region. Part 1. Fungi, lichens, clubmosses, horsetails and ferns. Kaliningrad, pp. 79-178. (In Russian).

Diederich, P., Kocourková, J., Etayo, J. \& Zhurbenko, M. 2007. The lichenicolous Phoma species (coelomycetes) on Cladonia. Lichenologist 39: 153-163. https: / / doi.org/10.1017/S0024282907006044

Diederich, P., Ertz, D., van den Broeck, D., van den Boom, P. P. G., Brand, M. \& Sérusiaux, E. 2009. New or interesting lichens and lichenicolous fungi from Belgium, Luxembourg and northern France. XII. Bulletin de la Société des Naturalistes Luxembourgeois 110: 75-92.

Frolov, I. V. \& Paukov, A. G. 2005. Lichens of the Bashkirsky Reserve. In: Ecology: from genes to ecosystems. Materials of the conference of young scientists. Yekaterinburg, pp. 299-300. (In Russian).

Gerasimova, I. P. (ed.). 1971. South-East of the European part of the USSR. Moscow. 459 pp. (In Russian).

Golovlev, A. A. \& Prokhorova, N. V. 2008. Nature of Samara region. Ulyanovsk. 252 pp. (In Russian).

Gudovicheva, A. V. \& Himelbrant, D. E. 2012. Contribution to the lichen flora of northern part of the Mid-Russian Upland. Vestnik of Tver State University 25(3): 150-164. (In Russian).

Hafellner, J. \& Wieser, B. 2000. Beitrag zur Diversität von Flechten und lichenicolen Pilzen im oststeirischen Hügelland unter besonderer Berücksichtigung der Gebiete mit anstehenden Vulkaniten (Steiermark, Österreich). Fritschiana 23: 1-26.

Hawksworth, D. L. 1979. The lichenicolous hyphomycetes. Bulletin of the British Museum, Botany 6: 183-300.

Hawksworth, D. L. \& Cole, M. S. 2002. Intralichen, a new genus for lichenicolous 'Bispora' and 'Trimmatostroma' species. Fungal Diversity 11: 87-97.

Himelbrant, D. E. 2005. Lichens. In: Vlasov, D. Y. (ed.). Park "Sergievka" - a complex monument of nature. St.-Petersburg, pp. 54-66. (In Russian).

Himelbrant, D. E., Motiejūnaitè, J., Pykälä, J., Schiefelbein, U. \& Stepanchikova, I. S. 2013. New records of lichens and allied fungi from the Leningrad Region, Russia. IV. Folia Cryptogamica Estonica 50: 23-31. https:/ / doi.org/10.12697/fce.2013.50.04
Himelbrant, D. E., Motiejūnaitė, J., Stepanchikova, I. S. \& Tagirdzhanova G. M. 2014. New records of lichens and allied fungi from the Leningrad Region, Russia. V. Folia Cryptogamica Estonica 51: 49-55. https: / / doi.org/ 10.12697/fce.2014.51.04

Himelbrant, D. E, Stepanchikova, I. S., Motiejūnaitè, J., Gagarina, L. V. \& Dyomina, A. V. 2016. New records of lichens and allied fungi from the Leningrad Region, Russia. VII. Folia Cryptogamica Estonica 53: 25-34. https://doi.org/10.12697/ fce.2016.53.04

Korchikov, E. S. \& Travkin, V. P. 2015. Concerning the lichens of the Buzulukskiy Bor National Park. Bulletin of Orenburg Scientific Centre of Russian Academy of Sciences Ural department 3: 1-10. (In Russian).

Korchikov, E. S., Travkin, V. P. \& Golov, Y. A. 2014. Concerning the lichens and non-lichenized fungi of the Buzulukskiy Bor National Park. Proceedings of Orenburg State Pedagogical University 2(10): 8-17. (In Russian).

Korchikov, E. S., Antipova, E. A., Lishtva, A. V., Melechin, A. V., Paukov, A. G., Sinichkin, E. A. \& Tsurykau, A. 2015. New species of lichens and lichenicolous fungi for Samara region from I. I. Sprygin Zhiguli State Reserve. Proceedings of Samara Scientific Centre of Russian Academy of Sciences 17(4): 72-76. (In Russian).

Kudinov, K. A. 2007. Zhiguli Reserve. Togliatti. 126 pp. (In Russian).

Kuznetsova, E. S., Motiejūnaitè, J., Stepanchikova, I. S., Himelbrant, D. E. \& Czarnota, P. 2012. New records of lichens and allied fungi from the Leningrad Region, Russia. III. Folia Cryptogamica Estonica 49: 31-37.

Mel'nik, V. A. 2000. Definitorium fungorum Rossiae. Classis Hyphomycetes. St. Petersburg. 371 pp. (In Russian).

Merkulova, O. S. 2006. Lichens of steppe zone of the South Ural and adjacent territories. PhD thesis. Saint Petersburg. 202 pp. (In Russian).

Navarro-Rosines, P. \& Roux, C. 2007. Pyrenidium. In: Nash, T. H. III, Gries, C. \& Bungartz, F. (eds). Lichen Flora of the Greater Sonoran Desert Region, Vol. 3. Tempe, pp. 404-405.

Pazhenkov, A. S. (ed.). 2010. Register of specially protected natural areas of regional importance in the Samara region. Samara. 259 pp. (In Russian).

Poroshina, L. N. (ed.) 2002. Atlas of the lands in Samara region. Samara. 100 pp. (In Russian).

Roux, C. 2012. Liste des lichens et champignons lichénicoles de France. Bulletin de la Société linnéenne de Provence 16: 1-220.

Stepanchikova, I. S., Schiefelbein, U., Alexeeva, N. M., Ahti, T., Kukwa, M., Himelbrant, D. E. \& Pykälä, J. 2011. Additions to the lichen biota of Berezovye Islands, Leningrad Region, Russia. Folia Cryptogamica Estonica 48: 95-106.

Urbanavichene, I. N. \& Urbanavichus, G. P. 2016. The lichen flora of the Mordouskii Reserve (an annotated species list). Moscow. 41 pp. (In Russian). 
Urbanavichene, I., Urbanavichus, G., Mežaka, A. \& Palice, Z. 2013. New records of lichens and lichenicolous fungi from the Southern Ural Mountains, Russia. II. Folia Cryptogamica Estonica 50: 73-80. https:/ /doi.org/10.12697/fce.2013.50.10

Urbanavichus, G. P. \& Urbanavichene, I. N. 2011. New records of lichens and lichenicolous fungi from the Ural Mountains, Russia. Folia Cryptogamica Estonica 48: 119-124.

Urbanavichus, G., Motiejūnaitè, J., Kukwa, M. \& Urbanavichene, I. 2007. Contribution to the biota of lichens and lichenicolous fungi of Murmansk region (NW Russia). Botanica Lithuanica 13(3): 197-202.

Vouaux, L. 1913. Synopsis des champignons parasites de lichens. Bulletin de la Société Mycologique de France 29: 33-128.

Yurchenko, E. O. \& Golubkov, V. V. 2003. The morphology, biology, and geography of a necrotrophic basidiomycete Athelia arachnoidea in Belarus. Mycological Progress 2: 275-284. https://doi. org/10.1007/s11557-006-0065-0

Zhurbenko, M. P. 2004. Lichenicolous and some interesting lichenized fungi from the Northern Ural, Komi Republic of Russia. Herzogia 17: 77-86.

Zhurbenko, M. P. 2007. The lichenicolous fungi of Russia: geographical overview and a first checklist. Mycologia Balcanica 4: 105-124.

Zhurbenko, M. P. 2008. Lichenicolous fungi from Russia, mainly from its Arctic. II. Mycologia Balcanica 5: 13-22.

Zhurbenko, M. P. 2009a. Lichenicolous fungi and some lichens from the Holarctic. Opuscula Philolichenum 6: 87-120.

Zhurbenko, M. P. 2009b. Lichenicolous fungi and lichens from the Holarctic. Part II. Opuscula Philolichenum 7: 121-186.

Zhurbenko, M. P. 2014. Lichenicolous fungi from Far East of Russia. Folia Cryptogamica Estonica 51: 113-119. https://doi.org/10.12697/ fce. 2014.51 .13

Zhurbenko, M. P. \& Ahti, T. 2005. A preliminary list of lichenicolous fungi of Republic of Karelia, Russia. In: Bondartseva, M. A. (ed.). Fungi in natural and anthropogenic ecosystems: Proceedings of the international conference dedicated to the centenary of the beginning by professor A. S. Bondarstev his research activity at the $V$. L. Komarov Botanical Institute RAS (24-28 April, 2005, Saint Petersburg). Vol. 1. Saint Petersburg, pp. 194-200.

Zhurbenko, M. P. \& Alstrup, V. 2004. Lichenicolous fungi on Cladonia mainly from the Arctic. Symbolae Botanicae Upsalienses 34(1): 477-499.

Zhurbenko, M. P. \& Gudovicheva, A. V. 2013. Zwackiomyces echinulatus and other lichenicolous fungi from Tula Region of Russia. Mikologiya $i$ fitopatologiya 47(1): 19-20.

Zhurbenko, M. P. \& Himelbrant, D. E. 2002. Lichenicolous fungi from the Kandalaksha Gulf, Karelia Keretina, Russia. Folia Cryptogamica Estonica 39: 51-59.

Zhurbenko, M. P. \& Kobzeva, A. A. 2014. Lichenicolous fungi from Northwest Caucasus, Russia. Herzogia 27: 377-396. https://doi.org/10.13158/ heia.27.2.2014.377

Zhurbenko, M. P. \& Kobzeva, A. A. 2016. Further contributions to the knowledge of lichenicolous fungi and lichenicolous lichens of the Northwest Caucasus, Russia. Opuscula Philolichenum 15: 37-56.

Zhurbenko, M. P. \& Santesson, R. 1996. Lichenicolous fungi from the Russian Arctic. Herzogia 12: $147-161$.

Zhurbenko, M. P. \& Zhdanov, I. S. 2013. Melaspilea galligena sp. nov. and some other lichenicolous fungi from Russia. Folia Cryptogamica Estonica 50: 89-99. https://doi.org/10.12697/ fce.2013.50.12

Zhurbenko, M. P., Hermansson, J. \& Pystina, T. N. 2012. Lichenicolous fungi from the Komi Republic of Russia. II. Folia Cryptogamica Estonica 49: 89-91.

Zmitrovich, I. 2004. The genus Athelia Pers. in Russia. Turczaninowia 7(4): 22-46. (In Russian). 